\title{
Appetitive Olfactory Learning and Long-Term Associative Memory in Caenorhabditis elegans
}

\author{
Saori Nishijima and Ichiro N. Maruyama* \\ Information Processing Biology Unit, Okinawa Institute of Science and Technology Graduate University, Okinawa, Japan
}

Because of the relative simplicity of its nervous system, Caenorhabditis elegans is a useful model organism to study learning and memory at cellular and molecular levels. For appetitive conditioning in C. elegans, food has exclusively been used as an unconditioned stimulus (US). It may be difficult to analyze neuronal circuits for associative memory since food is a multimodal combination of olfactory, gustatory, and mechanical stimuli. Here, we report classical appetitive conditioning and associative memory in C. elegans, using 1-nonanol as a conditioned stimulus (CS), and potassium chloride $(\mathrm{KCl})$ as a US. Before conditioning, C. elegans innately avoided 1-nonanol, an aversive olfactory stimulus, and was attracted by $\mathrm{KCl}$, an appetitive gustatory stimulus, on assay agar plates. Both massed training without an intertrial interval (ITI) and spaced training with a 10-min ITI induced significant levels of memory of association regarding the two chemicals. Memory induced by massed training decayed within $6 \mathrm{~h}$, while that induced by spaced training was retained for more than $6 \mathrm{~h}$. Animals treated with inhibitors of transcription or translation formed the memory induced by spaced training less

OPEN ACCESS

Edited by:

Jean-Christophe Sandoz, Centre National de la Recherche

Scientifique, France

Reviewed by:

Yukihisa Matsumoto,

Tokyo Medical and Dental University,

Japan

Ayse Yarali,

Leibniz Institute for Neurobiology,

Germany

${ }^{*}$ Correspondence:

Ichiro N. Maruyama

ichi@oist.jp

Received: 08 November 2016 Accepted: 13 April 2017 Published: 01 May 2017

Citation:

Nishijima S and Maruyama IN (2017)

Appetitive Olfactory Learning and Long-Term Associative Memory in Caenorhabditis elegans.

Front. Behav. Neurosci. 11:80. doi: 10.3389/fnbeh.2017.00080 efficiently than untreated animals, whereas the memory induced by massed training was not significantly affected by such treatments. By definition, therefore, memories induced by massed training and spaced training are classified as short-term memory (STM) and long-term memory (LTM), respectively. When animals conditioned by spaced training were exposed to 1-nonanol alone, their learning index was lower than that of untreated animals, suggesting that extinction learning occurs in C. elegans. In support of these results, $C$. elegans mutants defective in $n m r-1$, encoding an NMDA receptor subunit, formed both STM and LTM less efficiently than wild-type animals, while mutations in crh-1, encoding a ubiquitous transcription factor CREB required for memory consolidation, affected LTM, but not STM. The paradigm established in the present study should allow us to elucidate neuronal circuit plasticity for appetitive learning and memory in C. elegans.

Keywords: chemotaxis, extinction learning, massed and spaced trainings, olfactory conditioning, short-term and long-term memories

\section{INTRODUCTION}

Learning and memory are essential for animals to survive and reproduce in ever-changing environments. Appetitive conditioning is a form of associative learning and is the process by which a new predictive relationship between a cue (or action) and a reward is learned. During such conditioning, a stimulus acquires new motivational significance through association with the 
reward. Understanding appetitive conditioning is important for elucidating mechanisms of both learning and motivational processes (for reviews, see Martin-Soelch et al., 2007; Fanselow and Wassum, 2016). Appetitive conditioning has been demonstrated in many organisms, including Aplysia, dogs, Drosophila, honeybees, humans, rats, and snails (e.g., Pavlov, 1927; Alexander et al., 1984; Bouton and Peck, 1989; Schwaerzel et al., 2003; Giurfa et al., 2009; Austin and Duka, 2010; McDannald et al., 2011; Michel et al., 2011; Nargeot and Simmers, 2011; Burke et al., 2012; Eisenhardt, 2014; Andreatta and Pauli, 2015).

The major advantage of invertebrates for the study of learning and memory is the relative simplicity of their nervous systems. Caenorhabditis elegans is also an excellent model for studies of appetitive conditioning. Hedgecock and Russell (1975) found that C. elegans grown at 16,20 , or $25^{\circ} \mathrm{C}$ with food migrates to its growth temperature and then moves isothermally, suggesting that the animal associates its cultivation temperature with the presence of food, and remembers the association for several hours. In contrast, starved experience induced aversive responses to cultivation temperatures (Hedgecock and Russell, 1975; Mohri et al., 2005), although other recent studies have failed to find evidence of long-term association between temperature and presence or absence of bacterial food (Chi et al., 2007; Kobayashi et al., 2016). C. elegans is also able to form an association between the odorant benzaldehyde and the food content in its environment (Nuttley et al., 2002). Torayama et al. (2007) also reported that chemotaxis of $C$. elegans to butanone is enhanced by pre-exposure of the animal to the chemical in the presence of food. Based on this discovery, positive olfactory associative assays were designed to study learning and memory in C. elegans (Kauffman et al., 2010; Stein and Murphy, 2014).

The nervous system of $C$. elegans hermaphrodites has completely been reconstructed from serial electron micrographs of thin sections. Its 302 neurons form $\sim 7,000$ chemical synapses and $\sim 600$ gap junctions (White et al., 1986). The body is transparent throughout life, from fertilized egg to adult, so neural activities of living animals can be observed using genetically modified fluorescent proteins sensitive to voltage or $\mathrm{Ca}^{2+}$ concentration. C. elegans detects numerous volatile and watersoluble chemicals as attractants and repellents, mainly through its amphid sensilla (Ward, 1973; Dusenbery, 1974; Bargmann and Horvitz, 1991), and modulates its behavior based on experience (Hobert, 2003; Sasakura and Mori, 2013). Amphids are the largest chemosensory organs in C. elegans, and each one consists of 12 sensory neurons with ciliated dendrites, as well as a sheath and a socket glial cell (Ward et al., 1975; Ware et al., 1975). Amphid neurons serve various functions, including chemotaxis, thermotaxis, mechanosensation, osmotaxis, and dauer pheromone sensation (Bargmann and Mori, 1997; Driscoll and Kaplan, 1997; Riddle and Albert, 1997; de Bono and Maricq, 2005; Bargmann, 2006). Chemotaxis of C. elegans to cations, anions, cyclic nucleotides, and amino acids was first described by Ward (1973), and since then this list has been extended to include many olfactory stimuli (Bargmann et al., 1993). For example, 1-nonanol is a weak repellent for C. elegans (Bargmann et al., 1993), while potassium chloride $(\mathrm{KCl})$ is a strong attractant
(Ward, 1973). Both $\mathrm{K}^{+}$and $\mathrm{Cl}^{-}$ions are mainly sensed by a single sensory neuron, ASER (Ortiz et al., 2009).

As described above, appetitive conditioning has exclusively been demonstrated using food as an unconditioned stimulus (US) in C. elegans. Partly because behavior of C. elegans is dramatically affected by the presence or absence of food (Gray et al., 2005), the distinction between associative learning and nonassociative learning, which includes sensitization, habituation, and adaptation, is not clear (Bargmann, 2006). Rather than pairing chemical cues with food, which is a gustatory, olfactory and mechanical stimulus all in one, it would be preferable to use two defined chemical cues for conditioning C. elegans in order to analyze neuronal networks responsible for memory traces. In the present study, we developed a paradigm to study appetitive olfactory conditioning and associative memory in C. elegans. Under this paradigm, we conditioned animals with 1-nonanol as a conditioned stimulus (CS), and $\mathrm{KCl}$ as a US. Spaced training with an intertrial interval (ITI) induced longterm memory (LTM), while massed training without an ITI induced short-term memory (STM) which was disrupted by cold shock. The formation of LTM, but not STM was dependent on mRNA and protein synthesis, and required activity of genes shared by other model organisms, including Aplysia, Drosophila, and mice.

\section{MATERIALS AND METHODS}

\section{Strains Used}

The wild-type Bristol N2 and mutant strains, $c r h-1(t z 2)$ and nmr1(ak4), used in this study were obtained from the Caenorhabditis Genetics Center (University of Minnesota, Minneapolis, MN, USA). stau-1(tm2266) was from the National Bioresource Project for the Nematode (Tokyo Women's Medical University School of Medicine, Japan). $g l r-1(k y 176)$ was a generous gift from Andres Maricq (University of Utah, Salt Lake City, UT, USA). Animals were grown to adulthood on nematode growth medium (NGM) (50 $\mathrm{mM} \mathrm{NaCl}, 2 \%$ agar, 2.5\% peptone, $1.0 \mathrm{mM}$ cholesterol, $1.0 \mathrm{mM} \mathrm{CaCl}_{2}, 1.0 \mathrm{mM} \mathrm{MgSO} 4,25 \mathrm{mM}$ potassium phosphate, $\mathrm{pH}$ 6.0) seeded with Escherichia coli OP50 under unstarved conditions at $20^{\circ} \mathrm{C}$ using standard methods (Brenner, 1974).

\section{Chemotaxis Assay}

For olfactory chemotaxis assays, we used a $10-\mathrm{cm}$ square plate containing $14 \mathrm{ml}$ of $1.5 \%$ agar, $1.0 \mathrm{mM} \mathrm{CaCl}_{2}, 1.0 \mathrm{mM} \mathrm{MgSO}_{4}$, and $5 \mathrm{mM}$ potassium phosphate ( $\mathrm{pH}$ 6.0). Animals were collected by washing them off NGM plates with $0.25 \%$ aqueous gelatin solution, and were gently washed three times with $\sim 1.0 \mathrm{ml} 0.25 \%$ aqueous gelatin by decantation. Approximately 150 animals were placed along the central line of the agar plate, and gelatin solution was then removed as much as possible with a Kimwipe wick. Then, $3 \mu$ l each of $0.01 \% 1$-nonanol diluted with $100 \%$ ethanol $(\mathrm{EtOH})$, unless otherwise stated, were spotted at two places along the edge of the plate (Figure 1A). After covering the plate with a lid, animals were allowed to move freely for $10 \mathrm{~min}$ at room temperature (RT), and were then killed by placing a drop of chloroform on the lid. Animals in areas " $A$ " and " $C$ " (Figure 1A) 


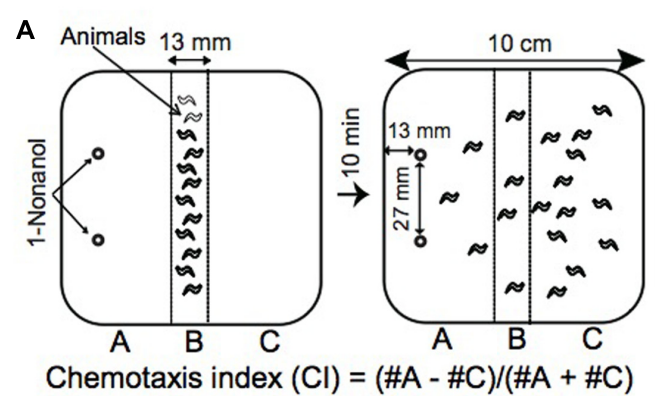

B

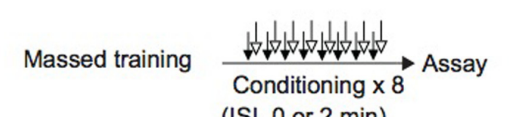

(ISI, 0 or $2 \mathrm{~min}$ )
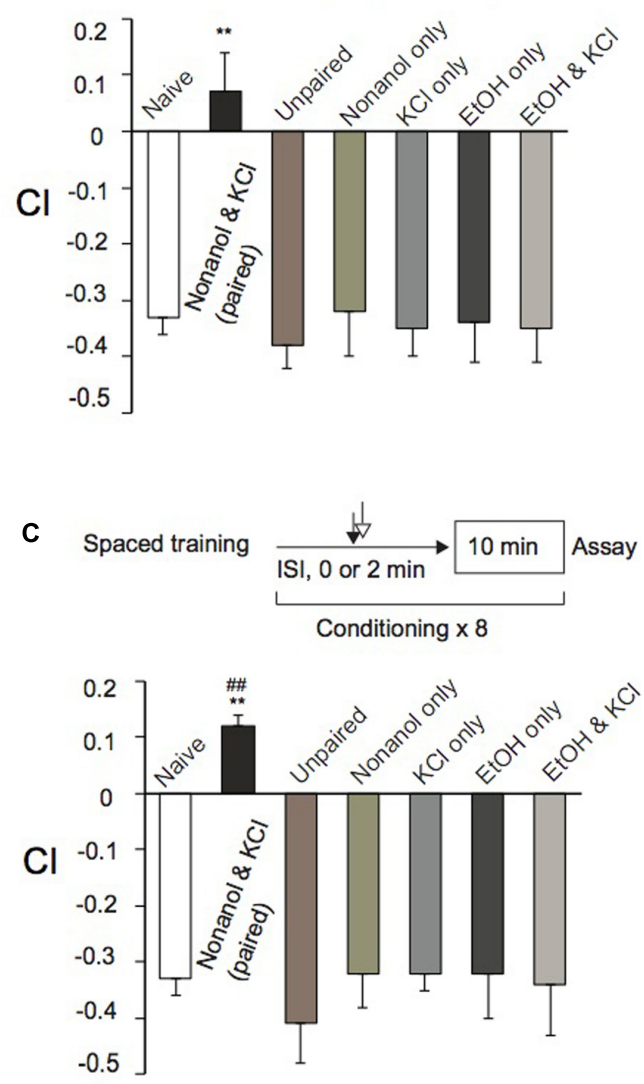

FIGURE 1 | Classical conditioning of Caenorhabditis elegans.

(A) Chemotaxis assay. After conditioning, an olfactory chemotaxis assay was performed on a square agar plate. Approximately 150 animals were placed along the central line of the plate. Then, $3 \mu \mathrm{l}$ of $0.01 \% 1$-nonanol solution diluted with $\mathrm{EtOH}$ was spotted at two places along the edge of the plate as shown. After 10-min incubation at RT, animals were killed with chloroform vapor. $\mathrm{Cl}$ was calculated using the equation shown, after counting the number of animals in sections "A" and "C." (B,C) Massed training and spaced training. Animals were conditioned eight times by massed training (B) or spaced training $\mathbf{( C )}$ with chemicals indicated. Paired training with 1-nonanol and $\mathrm{KCl}$, or $\mathrm{EtOH}$ and $\mathrm{KCl}$, was carried out consecutively without an intervening delay (ISI, $0 \mathrm{~s}$ ), while unpaired training with 1-nonanol and $\mathrm{KCl}$ was conducted consecutively with ISI (120 s). Chemotaxis assays were performed

(Continued)

\section{FIGURE 1 | Continued}

immediately after conditioning. Note that Cls of reference animals trained by massed training or spaced training with 1-nonanol and $\mathrm{KCl}$ (unpaired; ISI, 120 s), 1-nonanol only, $\mathrm{KCl}$ only, EtOH only, or EtOH and $\mathrm{KCl}$ were statistically indistinguishable from that of naïve animals. Asterisks $\left({ }^{* *}\right)$ indicate statistically significant differences $\left({ }^{*} p<0.01\right)$ determined by one-way ANOVA, followed by the Tukey-Kramer test for further comparison with Cls of unpaired, control animals. Cls of animals conditioned by spaced training (C), but not those conditioned by massed training (B), with 1-nonanol and $\mathrm{KCl}$ (paired) were statistically (\#\# < 0.01) different from the "O" base line when analyzed by using one sample $t$-test. Data are displayed as mean \pm SEM ( $n=9$ assays).

were counted to calculate a chemotaxis index (CI) using the equation shown in Figure 1A.

\section{Resource Localization Assay}

Potassium chloride localization assays were performed using $10-\mathrm{cm}$ Petri dishes divided into four quadrants, as described previously (Wicks et al., 2000) with modifications (Supplementary Figure S1A). Two adjacent quadrants were filled with agar (2\% agar, $10 \mathrm{mM}$ HEPES ( $\mathrm{pH} 7.2), 1.0 \mathrm{mM}$ $\mathrm{CaCl}_{2}$, and $1.0 \mathrm{mM} \mathrm{MgSO}$ ) supplemented with or without $\mathrm{KCl}$, ranging from 5 to $200 \mathrm{mM}$ (Supplementary Figure S1B). In quadrants without $\mathrm{KCl}$, sorbitol solution was added to adjust their osmolality (10-350 mOSM) to that of quadrants with $\mathrm{KCl}$. Osmolality of solutions was measured using an OSMOMAT osmometer (model 030-D; Gonotec, Berlin, Germany). Agar plates in adjacent quadrants were connected by placing a thin layer of $2 \%$ molten agar on top of the plastic separators. Animals were collected from an NGM plate by washing them off the plate in $0.25 \%$ aqueous gelatin solution, and after washing the animals three times with $\sim 1.0 \mathrm{ml}$ aqueous gelatin solution $(0.25 \%)$, approximately 100 animals in $\sim 100 \mu \mathrm{l}$ of $0.25 \%$ aqueous gelatin solution were placed at the intersection of the four quadrants. A Kimwipe wick was used to remove as much gelatin solution as possible. After $30 \mathrm{~min}$ incubation at RT, animals were killed by placing a drop of chloroform on the lid. Animals in each quadrant were counted to calculate performance index (PI), dividing the number of animals on quadrants containing $\mathrm{KCl}$ by the total number of animals on the entire plate (Supplementary Figure S1A).

\section{General Conditioning}

1-Nonanol solution $(0.01 \%, 30 \mathrm{ml}$, diluted with $100 \% \mathrm{EtOH})$ was placed in a 500-ml beaker, and a small plastic dish, $6 \mathrm{~cm}$ in diameter, containing $10 \mathrm{ml}$ of $160 \mathrm{mM} \mathrm{KCl}$ was placed on a plastic stand, $1.5 \mathrm{~cm}$ high, in the beaker. Well-fed animals 4 days after hatching were collected from an NGM plate by washing the plate three times with $\sim 1.0 \mathrm{ml}$ aqueous gelatin solution $(0.25 \%)$. Then animals were transferred to a transparent plastic pipe (polymethylmethacrylate; $1.5 \mathrm{~cm}$ long, $3 \mathrm{~cm}$ external diameter, 2-mm wall thickness), the bottom of which was closed with a nylon mesh sheet (pore size; $30 \mu \mathrm{m}$ ). Animals in the plastic container were lowered into the beaker slowly $(\sim 10 \mathrm{~s})$ to be stimulated with 1-nonanol vapor as a CS, and then briefly $(<1.0 \mathrm{~s})$ with $\mathrm{KCl}$ as a US. Animals were washed once by gently immersing the container in an excess $(100 \mathrm{ml})$ of doubly 

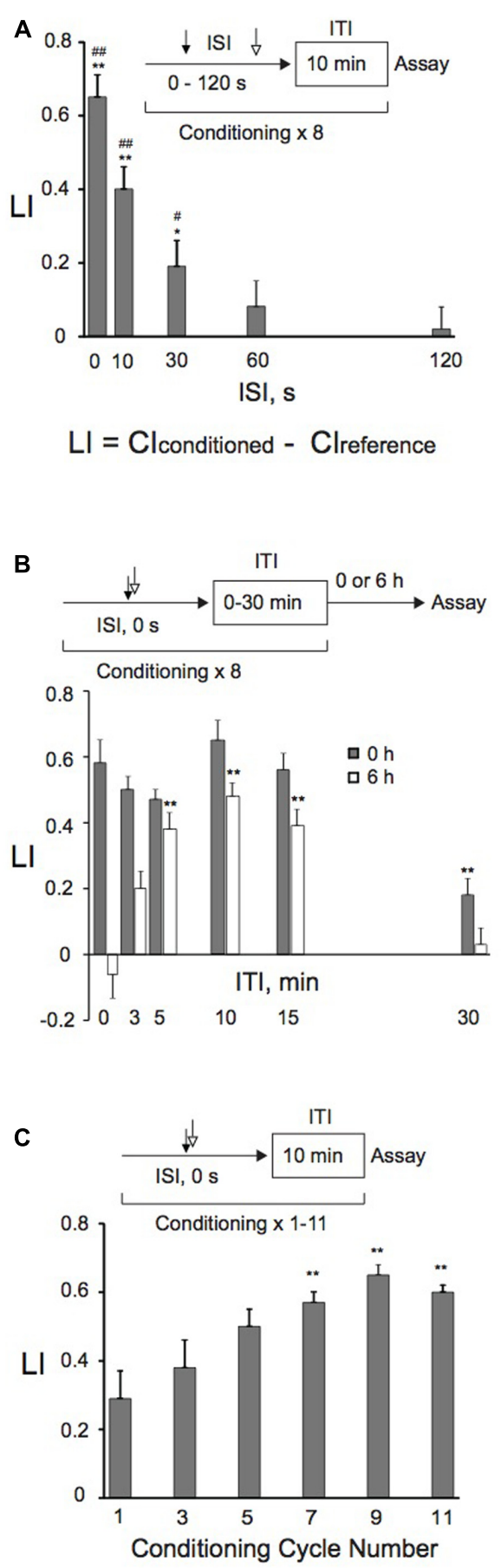

FIGURE 2 | Effects of ISI and ITI lengths, or conditioning cycle numbers on memory retention. (A) Effects of ISI lengths on memory formation. Animals were conditioned with $0.01 \% 1$-nonanol and $160 \mathrm{mM} \mathrm{KCl}$ consecutively without an intervening delay (0 s), or 10, 30, 60, or 120 s later with $160 \mathrm{mM} \mathrm{KCl}$ after the end of 1-nonanol stimulation by eight-cycle spaced training with a 10-min ITI. Chemotaxis assays were carried out immediately after conditioning. Asterisks $\left({ }^{*} p<0.05,{ }^{* *} p<0.01\right)$ indicate statistically significant differences determined by one-way ANOVA, followed by the Tukey-Kramer test for further comparison with LI values of animals conditioned with ISI (120 s). LIs of animals conditioned with various ISIs were statistically

(Continued)

\section{FIGURE 2 | Continued}

( $p<0.05$, \#\# $p<0.01)$ different from the "0" base line when analyzed by using one sample $t$-test. An equation for calculation of learning index (LI) is also shown, and $\mathrm{Cl}_{\text {reference }}$ is $\mathrm{Cl}$ of animals treated first with $100 \% \mathrm{EtOH}$ and then with $160 \mathrm{mM} \mathrm{KCl}$ by massed or spaced training unless otherwise stated. Bars are means \pm SEM ( $n=6-9$ assays). (B) ITI effects on memory formation and retention. Animals were conditioned with $0.01 \% 1$-nonanol and $160 \mathrm{mM}$ $\mathrm{KCl}$ consecutively without an intervening delay (ISI, $0 \mathrm{~s}$ ), using eight-cycle spaced training with indicated ITI lengths. Chemotaxis assays were performed immediately (gray bars) or $6 \mathrm{~h}$ (open bars) after conditioning. Asterisks (**) indicate statistically significant differences $(p<0.01)$ determined by one-way ANOVA, followed by the Tukey-Kramer test for further comparison with LIs of animals conditioned without an ITI. LI values were calculated from the equation shown in (A) using $\mathrm{Cl}_{\text {reference values of animals treated with } 100 \%}$ EtOH and $160 \mathrm{mM} \mathrm{KCl}$. Bars are means \pm SEM ( $n=6-9$ assays). (C) Effects of the number of conditioning cycles on memory formation. Animals were conditioned with $0.01 \% 1$-nonanol and $160 \mathrm{mM} \mathrm{KCl}$ consecutively without an intervening delay (ISI, $0 \mathrm{~s})$, using a 10-min ITI and repeating the conditioning 1-11 times. Immediately after conditioning, chemotaxis assays were performed. Asterisks $(* *)$ indicate statistically significant differences $(p<0.01)$ determined by one-way ANOVA, followed by the Tukey-Kramer test for further comparison with LIs of single-conditioned animals. LI values were calculated from the equation shown in (A) using $\mathrm{Cl}_{\text {reference }}$ values of animals treated with $100 \% \mathrm{EtOH}$ and $160 \mathrm{mM} \mathrm{KCl}$. Bars are means $\pm \mathrm{SEM}(n=9$ assays).

deionized water $\left(\mathrm{ddH}_{2} \mathrm{O}\right.$; Millipore Elix $10 \mathrm{UV}$, followed by Millipore Milli-Q Synthesis A10, Merck Millipore), and an excess amount of water was removed by placing the container on a paper towel. The container was then placed on a chemotaxis assay plate for $10 \mathrm{~min}$, unless otherwise stated, for spaced training as described below. For massed training, this resting process was omitted. This procedure was repeated eight times unless otherwise stated, and fresh $\mathrm{ddH}_{2} \mathrm{O}$ was used each time for washing, so as to prevent contamination. Then, animals were collected in a $1.5 \mathrm{ml}$ tube by suspending them in $\sim 1.0 \mathrm{ml}$ of $0.25 \%$ aqueous gelatin, and were used immediately for chemotaxis assay, or were incubated on an NGM plate with an OP50 lawn at RT until post-training chemotaxis assay. A learning index (LI) was calculated by subtracting CI of reference animals mockconditioned with $100 \% \mathrm{EtOH}$ and $160 \mathrm{mM} \mathrm{KCl}$ from that of conditioned animals (Figure 2A). LI values in Figures 5, 6 were calculated by subtracting of CI of unpaired (ISI, $120 \mathrm{~s}$ ) animals stimulated with 1-nonanol and $\mathrm{KCl}$ from that of paired (ISI, $0 \mathrm{~s}$ ) animals.

\section{Conditioning with Various Interstimulus Intervals}

An interval between stimulations, an interstimulus interval (ISI), with $0.01 \%$ 1-nonanol diluted with $\mathrm{EtOH}$ and $160 \mathrm{mM} \mathrm{KCl}$ was varied, ranging from $0 \mathrm{~s}$ to $2 \mathrm{~min}$. In the present study, ISI is a period of time between the end of CS stimulation and the on-set of US stimulation. Animals in a plastic container were lowered into a beaker saturated with vapor from $0.01 \% 1$-nonanol diluted with $\mathrm{EtOH}$ for $\sim 10 \mathrm{~s}$, and were gently washed with $\mathrm{ddH}_{2} \mathrm{O}$ $(100 \mathrm{ml})$, followed by resting on a chemotaxis assay plate until a designated period of time. Then animals were immersed in $160 \mathrm{mM} \mathrm{KCl}$ solution briefly $(<1.0 \mathrm{~s})$, and were gently washed by immersing the animals in $\mathrm{ddH}_{2} \mathrm{O}(500 \mathrm{ml})$. After removing excess water by placing the container on a paper towel, animals 
were rested on a chemotaxis assay plate for $10 \mathrm{~min}$ at RT until the next cycle of conditioning. This conditioning was repeated eight times. In case of "ISI, 0 s," animals were lowered into a beaker saturated with vapor from 0.01\% 1-nonanol and 100\% EtOH for approximately $10 \mathrm{~s}$, and were then dipped into $160 \mathrm{mM}$ $\mathrm{KCl}$ without washing with $\mathrm{ddH}_{2} \mathrm{O}$.

\section{Conditioning with Various Intertrial Intervals}

Animals were consecutively conditioned with $0.01 \%$ 1-nonanol, which was diluted with EtOH, and $160 \mathrm{mM} \mathrm{KCl}$ as described above in Section "General Conditioning," and were gently washed with $\mathrm{ddH}_{2} \mathrm{O}$. For massed training, animals were subjected to the next cycle of conditioning without rest. For spaced training, animals in a plastic container rested on a chemotaxis assay plate for $10 \mathrm{~min}$, unless otherwise stated, before the next conditioning. Conditioning was repeated eight times unless otherwise stated. After completion of conditioning, animals were washed with $\sim 1.0$ - $\mathrm{ml} 0.25 \%$ aqueous gelatin solution, and were either subjected to the chemotaxis assay or incubated on an NGM plate with an OP50 lawn at $20^{\circ} \mathrm{C}$ until post-training chemotaxis assay. All other aspects of conditioning, testing, and scoring were as described above in Section "General Conditioning".

\section{Cold Shock}

Immediately after conditioning, animals in a container were gently immersed in ice-cold $\mathrm{ddH}_{2} \mathrm{O}$ for 5 s. Excess water was removed by placing the container on a paper towel, and animals were either subjected to chemotaxis assay or incubated on an NGM plate with an OP50 lawn at $20^{\circ} \mathrm{C}$ until posttraining chemotaxis assay. All other aspects of conditioning, testing, and scoring were as described above in Section "General Conditioning".

\section{Extinction Learning}

After "general spaced training" (ISI, $0 \mathrm{~s}$; ITI, $10 \mathrm{~min}$; eight cycles), animals were incubated on an NGM plate with an OP50 lawn for $3 \mathrm{~h}$ at $20^{\circ} \mathrm{C}$. Then, animals were collected by washing them off the plate with $0.25 \%$ aqueous gelatin solution $(\sim 1.0 \mathrm{ml})$, and were conditioned with only CS by slowly ( $\sim 10$ s) lowering the container into a $500-\mathrm{ml}$ beaker saturated with vapor of $0.01 \% 1$-nonanol diluted with EtOH. Animals were gently washed by immersing the container in $\mathrm{ddH}_{2} \mathrm{O}(100 \mathrm{ml})$, and then the container was placed on a paper towel to remove excess water. This conditioning was repeated eight times without an ITI. Chemotaxis assays were performed immediately after conditioning, and all other aspects of conditioning, testing, and scoring were as described above in Section "General Conditioning”.

\section{Inhibitor Treatment}

Nematode growth medium agar plates containing inhibitors were prepared by mixing molten NGM agar with $0.3 \mu \mathrm{g} / \mathrm{ml}$ cycloheximide (Sigma, Saint Louis, MO, USA), $0.3 \mu \mathrm{g} / \mathrm{ml}$ anisomycin (A.G. Scientific, San Diego, CA, USA), or $0.1 \mu \mathrm{g} / \mathrm{ml}$ actinomycin D (MP Biomedicals, Solon, OH,
USA) (final concentration). One day before experiments, plates were spread with OP50, and were left at RT overnight. Animals were cultivated on the plates for $2 \mathrm{~h}$ at $20^{\circ} \mathrm{C}$ before spaced training, or for $4 \mathrm{~h}$ at $20^{\circ} \mathrm{C}$ before massed training. Under the conditions, $\sim 50 \%$ of protein synthesis of the animal was inhibited by this treatment (Amano and Maruyama, 2011).

\section{Motility Assay}

Motility of wild-type animals treated with inhibitors as described above was examined. Animals were collected in $\sim 1.0 \mathrm{ml}$ of $0.25 \%$ aqueous gelatin solution, and were placed on an agar plate consisting of $1.5 \%$ agar, $1.0 \mathrm{mM} \mathrm{CaCl}_{2}, 1.0 \mathrm{mM} \mathrm{MgSO}_{4}$, and $5 \mathrm{mM}$ potassium phosphate ( $\mathrm{pH}$ 6.0). A Kimwipe wick was used to remove as much solution as possible. Once animals started moving in a forward direction, the number of body bends during 10 s was counted for 20 animals. Since C. elegans moves forward using a stereotypical sine wave from head to tail, one sine wave was counted as one body bend (Supplementary Table S1).

In the same way, motility of wild-type and mutants (20 animals each) was also analyzed after being conditioned with either $100 \% \mathrm{EtOH}$ and $160 \mathrm{mM} \mathrm{KCl}$, or $0.01 \%$ 1-nonanol diluted with $\mathrm{EtOH}$ and $160 \mathrm{mM} \mathrm{KCl}$ by massed training or spaced training (Supplementary Table S2).

\section{Statistical Analysis}

Statistical analysis of data was performed using Microsoft ${ }^{\circledR}$ Excel 2011 for Macintosh ${ }^{\circledR}$ with the add-in software Statcel3 (OMS Publ., Saitama, Japan). All data were checked for normality of distribution and homogeneity of variance using $\chi^{2}$ goodness of fit test $(p<0.05)$, and were evaluated using Student's $t$-test for comparisons between pairs of groups, or one-way analysis of variance (ANOVA) for multiple comparisons between groups. If ANOVA results were significant $(p<0.05)$, the Tukey-Kramer post hoc test was used. Results are reported as mean \pm the standard error of the mean (SEM).

\section{RESULTS}

\section{Appetitive Conditioning of C. elegans with 1-Nonanol and $\mathrm{KCl}$}

Caenorhabditis elegans innately avoided an olfactory cue, 1-nonanol, and was attracted to $\mathrm{KCl}$ on an agar plate assay (Supplementary Figure S1) as previously observed (Ward, 1973; Bargmann et al., 1993). Animals were repelled in a dosedependent manner by 1-nonanol concentrations ranging from 0.01 to $10 \%$ (Supplementary Figure S1C), and were maximally attracted by $\mathrm{KCl}$ ranging from 50 to $200 \mathrm{mM}$ (Supplementary Figure $\mathrm{S} 1 \mathrm{~B}$ ). Using 1-nonanol and $\mathrm{KCl}$ as a CS and a US, respectively, we developed classical conditioning protocols to study associative learning and memory in C. elegans. We chose $0.01 \%$ 1-nonanol, diluted with $\mathrm{EtOH}$, as a CS, since $0.01 \%$ is the lowest concentration of 1-nonanol to which the animals could respond in a dose-dependent manner (Supplementary Figure S1C). $160 \mathrm{mM} \mathrm{KCl}$ was used as a US since osmolality (300 mOSM) of the solution is close to that of culture buffer and 
media for C. elegans. Animals repeatedly treated with both $0.01 \%$ 1-nonanol, which was diluted with $100 \% \mathrm{EtOH}$, and $160 \mathrm{mM}$ $\mathrm{KCl}$ by massed training (without an ITI) were not repelled from 1-nonanol, since their CI values were not significantly higher than the " 0 " base line. Furthermore, animals repeatedly treated with the chemicals by spaced training (with a 10-min ITI) were attracted to 1-nonanol, since the CI values were significantly higher than the base line (Figures 1B,C). Reference animals treated by massed training or spaced training with $0.01 \%$ 1-nonanol and $160 \mathrm{mM} \mathrm{KCl}$ (unpaired with ISI, $120 \mathrm{~s}$ ), or with $0.01 \%$ 1-nonanol alone, $160 \mathrm{mM} \mathrm{KCl}$ alone, $100 \% \mathrm{EtOH}$ alone, or $100 \% \mathrm{EtOH}$ and $160 \mathrm{mM} \mathrm{KCl}$ avoided 1-nonanol, and their CIs were not statistically different from that of naïve animals in the chemotaxis assay (Figures 1B,C). Wild-type animals' sensitivity to 1 -nonanol and $160 \mathrm{mM} \mathrm{KCl}$, and their locomotion were not affected by the chemical treatments during massed or spaced training (Figures 1B,C and Supplementary Table S2). These results demonstrated that animals conditioned by the massed training using 1-nonanol as a $\mathrm{CS}$ and $\mathrm{KCl}$ as a US associated the two signals, and were not repelled by 1-nonanol, and that animals conditioned by the spaced training switched their behavior from repulsion to attraction in response to 1-nonanol stimulation.

\section{Optimal ISI, ITI and Training Cycle Numbers for Memory Retention}

We studied the effect of ISIs on memory retention to optimize the conditioning protocols. "Forward conditioning," in which presentation of a CS precedes that of a US, often produces optimal conditioning (e.g., Jones, 1962; Schneiderman and Gormezano, 1964; Hawkins et al., 1986), while "backward conditioning" can also successfully induce the same memory to those by "forward conditioning" (Dostalek, 1976; Spetch et al., 1981; Durkovic and Damianopoulos, 1986; Amano and Maruyama, 2011). Alternatively, "backward conditioning" in which an aversive US precedes a CS establishes a conditioned approach to the aversive stimulus as a signal for "relief" (e.g., Tanimoto et al., 2004; Andreatta et al., 2012; for a review, see Gerber et al., 2014). Animals that were backwardly conditioned with $160 \mathrm{mM}$ $\mathrm{KCl}$ first and then with $0.01 \%$ 1-nonanol severely twitched, and could not crawl on the agar surface. Therefore, we tested the effect of ISIs on learning and memory only by "forward conditioning." Consecutive conditioning with 1-nonanol and $\mathrm{KCl}$ without an intervening delay most efficiently induced memory, and the efficiency decreased exponentially as the ISIs increased (Figure 2A). Almost no memory was formed with ISIs $\geq 60 \mathrm{~s}$, consistent with our previous results in aversive olfactory conditioning (Amano and Maruyama, 2011).

We also analyzed effects of ITIs on memory retention. Animals were given eight cycles of conditioning, of which ITI lengths ranged from 0 min through $30 \mathrm{~min}$. Memory retention was analyzed by measuring LI values immediately and $6 \mathrm{~h}$ after training. When assayed immediately after training, there were no statistically significant differences among LIs, except for those of animals trained with a 30-min ITI (Figure 2B). When assayed $6 \mathrm{~h}$ after training, in contrast, LIs of trained animals were elevated as the ITI lengths were increased up to $10 \mathrm{~min}$, and then the LIs gradually decreased when it was longer than $10 \mathrm{~min}$. These results demonstrate that the 10 -min ITI is most efficient for animals to retain the memory for $6 \mathrm{~h}$ after training, and are consistent with those of aversive olfactory conditioning (Amano and Maruyama, 2011).

These results demonstrated that consecutive conditioning (ISI, $0 \mathrm{~s}$ ) with $0.01 \%$ 1-nonanol and $160 \mathrm{mM} \mathrm{KCl}$ efficiently induced associative memory. Associative memory induced by spaced training with a 10 -min ITI was most efficiently retained at $6 \mathrm{~h}$ after the training under the conditions tested. Therefore, using consecutive spaced training (ISI, 0 s) with a 10-min ITI, we examined the effect of conditioning cycle numbers with $0.01 \%$ 1-nonanol and $160 \mathrm{mM} \mathrm{KCl}$ on memory formation. Spaced training with $>7$ cycles induced statistically significant $(p<0.01)$ enhancement of memory formation in comparison to single conditioning, demonstrating that repeated conditioning is required for efficient induction of associative memory (Figure 2C).

\section{Memory Retention and Extinction}

With optimized ISI and ITI lengths, as well as with optimal conditioning trial numbers, we also analyzed retention time of memory induced by massed or spaced training. After completion of training, animals were transferred to NGM plates with bacteria, where they were allowed to move and eat at $20^{\circ} \mathrm{C}$ for various time intervals until post-training chemotaxis assay. LI values induced by eight-cycle massed and spaced training were statistically indistinguishable when assayed immediately after training (Figure 3A). However, memory induced by massed training was no longer observable at $6 \mathrm{~h}$. LI values after single conditioning or three-cycle massed training were statistically smaller than those induced by eight-cycle massed training when assayed immediately after conditioning, and the memory became unobservable more rapidly than those after eight-cycle massed training. Memory induced by eight-cycle spaced training was observable beyond $6 \mathrm{~h}$ after conditioning as consolidated LTM shown below. After consolidation of associated memory between CS and US, further presentations of the CS alone (reactivation) can destabilize it. Reactivation can lead to extinction, a decrease of the response resulting from new associative memory between CS and no US (Myers and Davis, 2002; Suzuki et al., 2004). When animals conditioned by spaced training using 1-nonanol and $\mathrm{KCl}$ were exposed to 1 -nonanol alone, their LI values were lower than those of animals stimulated with $\mathrm{EtOH}$ as a negative control (Figure 3B), suggesting that extinction learning occurs in C. elegans. This decrease is not due to habituation or adaptation, since chemotactic activity of animals exposed repeatedly to the CS alone or to $100 \% \mathrm{EtOH}$ is similar to that of naïve animals (Figure 1B).

\section{Sensitivity of Memory to Retrograde Amnesia}

Short-term memory is vulnerable to disruption by factors such as anesthesia and cold shock (Tully et al., 1994). Therefore, we examined whether memory induced by massed training or spaced training is sensitive to cold shock. Immediately after massed 


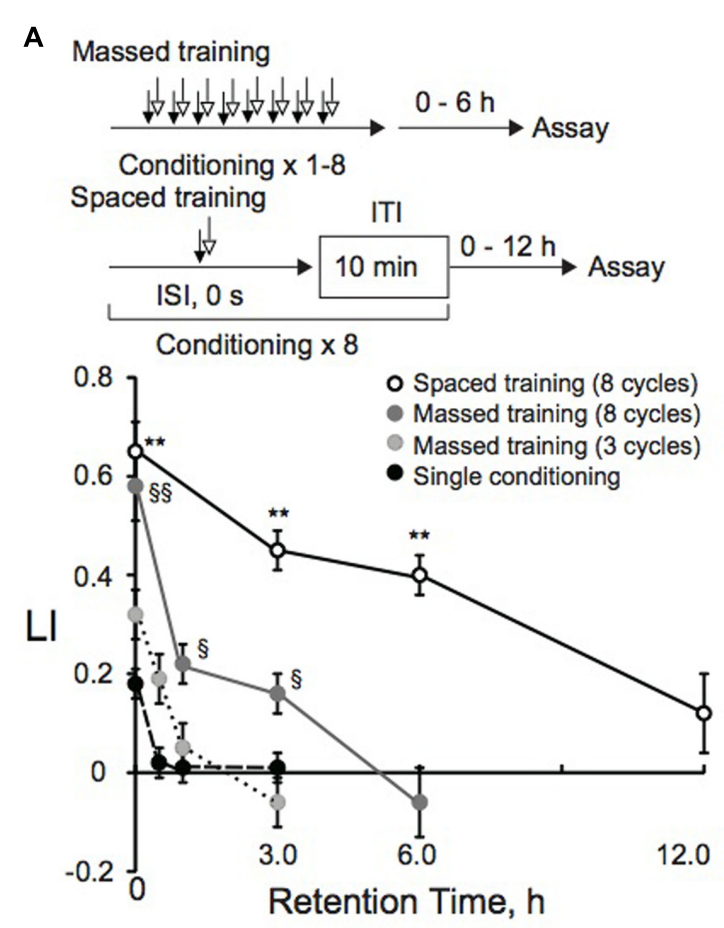

B

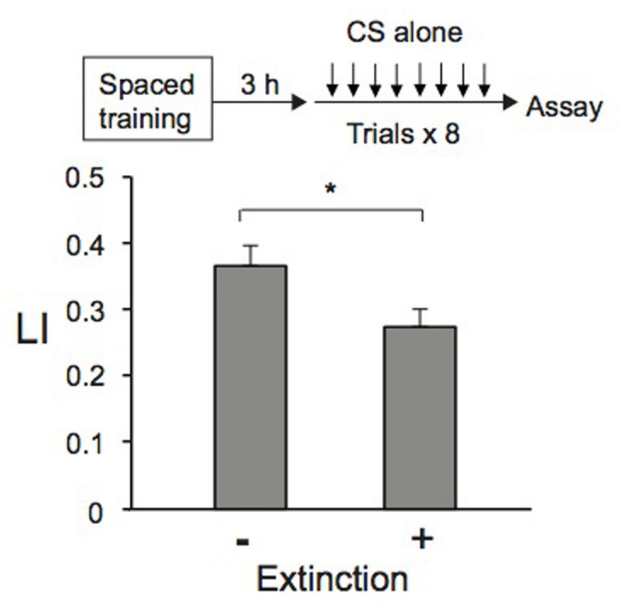

FIGURE 3 | Memory formation and retention after massed, spaced, or extinction training. (A) Memory retention curve. Animals were conditioned with $0.01 \% 1$-nonanol and $160 \mathrm{mM} \mathrm{KCl}$ indicated numbers of cycles by massed or spaced training. Their LIs were measured at indicated time intervals after conditioning. Asterisks indicate statistically significant differences $(* * p<0.01)$ determined by one-way ANOVA, followed by the Tukey-Kramer test for further comparison of LIs of animals conditioned by spaced training with those of animals conditioned by single conditioning or massed training. However, LIs of animals conditioned by eight-cycle spaced training or massed training were statistically indistinguishable from each other, when analyzed by using a two-sided Student's $t$-test. LIs of animals conditioned by the eight-cycle massed training showed statistically significant differences ( ${ }^{\$} p<0.05,{ }^{s \varsigma} p<0.01$ ) determined by one-way ANOVA, followed by the Tukey-Kramer test for further comparison of LIs of animals conditioned

(Continued)

\section{FIGURE 3 | Continued}

by single conditioning or three-cycle massed training. LI values were calculated from the equation shown in Figure 2A using $\mathrm{Cl}_{\text {reference values of }}$ animals treated with $100 \% \mathrm{EtOH}$ and $160 \mathrm{mM} \mathrm{KCl}$. Data are means \pm SEM ( $n=6-9$ assays). (B) Extinction learning after spaced training. Animals were conditioned with $0.01 \% 1$-nonanol and $160 \mathrm{mM} \mathrm{KCl}$ by eight-cycle spaced training with a 10-min ITI. They were then transferred to an NGM plate with a bacterial lawn. After $3 \mathrm{~h}$ incubation at $20^{\circ} \mathrm{C}$, animals were treated eight times (without ITI) only with $0.01 \% 1$-nonanol diluted with $\mathrm{EtOH}$ or $100 \% \mathrm{EtOH}$. Immediately after the treatment, chemotaxis assays were performed. LIs of animals with and without extinction trials were statistically different $\left(^{*} p<0.05\right)$ when analyzed using a two-sided Student's $t$-test. LI values were calculated from the equation shown in Figure $\mathbf{2 A}$ using $\mathrm{Cl}_{\text {reference }}$ values of animals treated with $100 \% \mathrm{EtOH}$ and $160 \mathrm{mM} \mathrm{KCl}$. Data are displayed as means \pm SEM ( $n=9$ assays).

training or spaced training, animals were treated with cold shock by immersing them in ice-cold $\mathrm{dd}_{2} \mathrm{O}$ for $5 \mathrm{~s}$. After recovering at RT for $5 \mathrm{~min}$ or $3 \mathrm{~h}$ (massed training), or for $5 \mathrm{~min}$ or $6 \mathrm{~h}$ (spaced training) on NGM plates with bacteria, animals were assayed for chemotaxis to 1-nonanol. Cold shock did not affect memory retention induced by spaced training, while LI after massed training was markedly decreased (Figure 4). Of the memory formed by massed training, approximately $2 / 3$ was cold shock-sensitive memory and the rest was cold shock-resistant memory, when assayed 5 min after cold shock. Cold shock did not significantly affect memory retained at $3 \mathrm{~h}$ after massed training. This may be partly because the memory decayed quickly even without cold shock. Since memory after spaced training was resistant to cold shock, it might be consolidated during repetitive conditioning with a 10 -min ITI.

\section{Effect of Translation and Transcription Inhibitors on Memory Formation}

As described above, memory induced by spaced training was resistant to cold shock, suggesting that it might be LTM, formation of which can be inhibited by treatments of animals with transcription and translation inhibitors (Flexner et al., 1962; Agranoff and Klinger, 1964; Barondes and Jarvik, 1964; Flood et al., 1973; Mizumori et al., 1987; Bourtchuladze et al., 1994; Tully et al., 1994; Epstein et al., 2003; Jarome and Helmstetter, 2014). Therefore, we examined the effect of a translation inhibitor, anisomycin or cycloheximide, and a transcription inhibitor, actinomycin $\mathrm{D}$, on memory formation by massed or spaced training. Before spaced training, animals were cultivated for $2 \mathrm{~h}$ on NGM plates spread with bacteria in the presence of $0.3 \mu \mathrm{g} / \mathrm{ml}$ anisomycin, $0.3 \mu \mathrm{g} / \mathrm{ml}$ cycloheximide, or $0.1 \mu \mathrm{g} / \mathrm{ml}$ actinomycin D (final concentration), and then during ITI, animals were placed on NGM plates spread with bacteria that contained the inhibitor. Therefore, animals were cultivated on NGM plates containing the inhibitor for $\sim 3.2 \mathrm{~h}$ in total. Under these conditions, approximately $50 \%$ of protein synthesis in C. elegans was inhibited (Amano and Maruyama, 2011). Inhibitor-treated animals conditioned by spaced training formed associative memory between 1-nonanol and $\mathrm{KCl}$ less effectively than untreated animals, indicating that both translation and transcription are required for memory formation (Figure 5). In contrast, memory formation after massed training required 


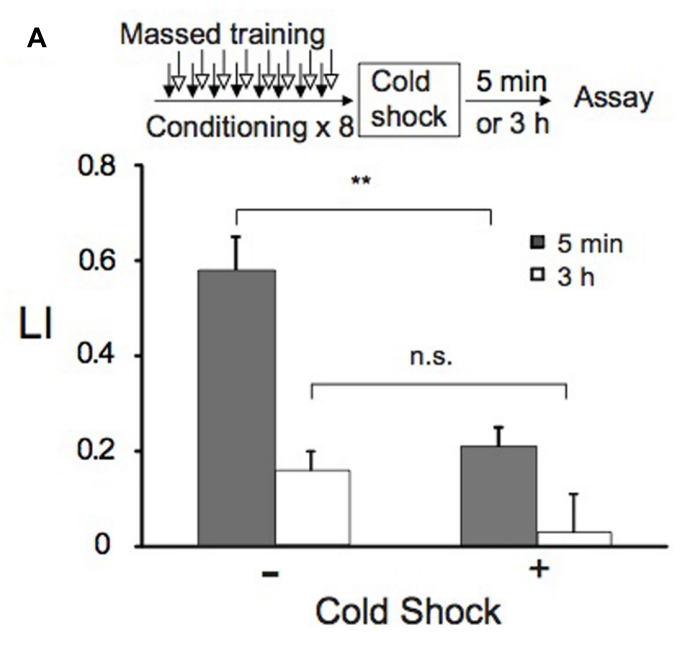

B Spaced training

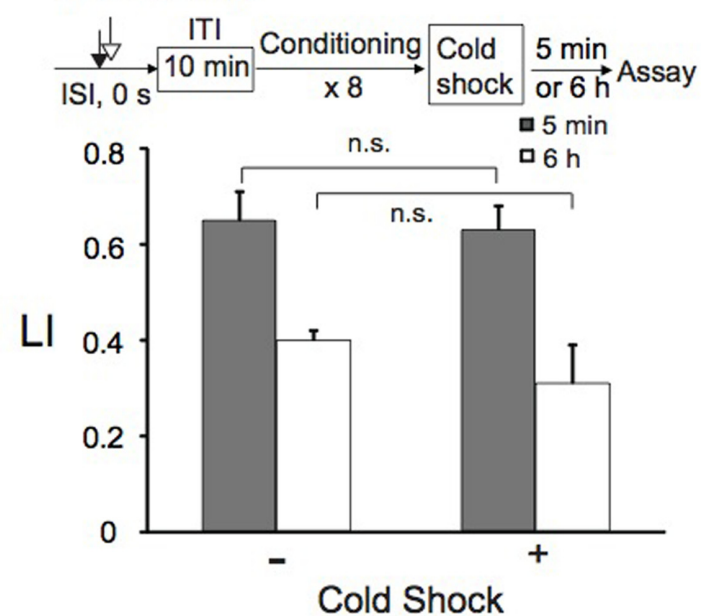

FIGURE 4 | Short-term memory (STM), but not LTM, is disrupted by cold shock. Animals were conditioned with $0.01 \% 1$-nonanol and $160 \mathrm{mM}$ $\mathrm{KCl}$ by eight-cycle massed training (A) or eight-cycle spaced training with a 10-min ITI (B). Immediately after conditioning, animals were immersed in ice-cold $\mathrm{ddH}_{2} \mathrm{O}$ for $5 \mathrm{~s}$ as cold shock. Chemotaxis assays were performed $5 \mathrm{~min}$ (gray bars) and 3 or $6 \mathrm{~h}$ (open bars) after the recovery from cold shock. Note that only LI values of animals with and without cold shock after massed training were statistically different $\left({ }^{* *} p<0.01\right)$ and that all the other LIs, which include LIs $3 \mathrm{~h}$ after massed training, with cold shock were statistically indistinguishable from those without cold shock, when analyzed using a two-sided Student's t-test. LI values were calculated from the equation shown in Figure 2A using $\mathrm{Cl}_{\text {reference }}$ values of animals treated with $100 \% \mathrm{EtOH}$ and $160 \mathrm{mM} \mathrm{KCl}$. Data are displayed as means \pm SEM ( $n=6-9$ assays). n.s., not significant.

neither translation nor transcription, since memory was normally induced in animals cultivated on NGM plates in the presence of the inhibitor for $4 \mathrm{~h}$ before training started. Inhibitor treatment of animals under the conditions used affected neither motility (Supplementary Table S1), nor chemotaxis to 1-nonanol or to $160 \mathrm{mM} \mathrm{KCl}$ (Supplementary Figure S2). In the experiments of Figure 5, LI values were calculated by subtracting of CI of

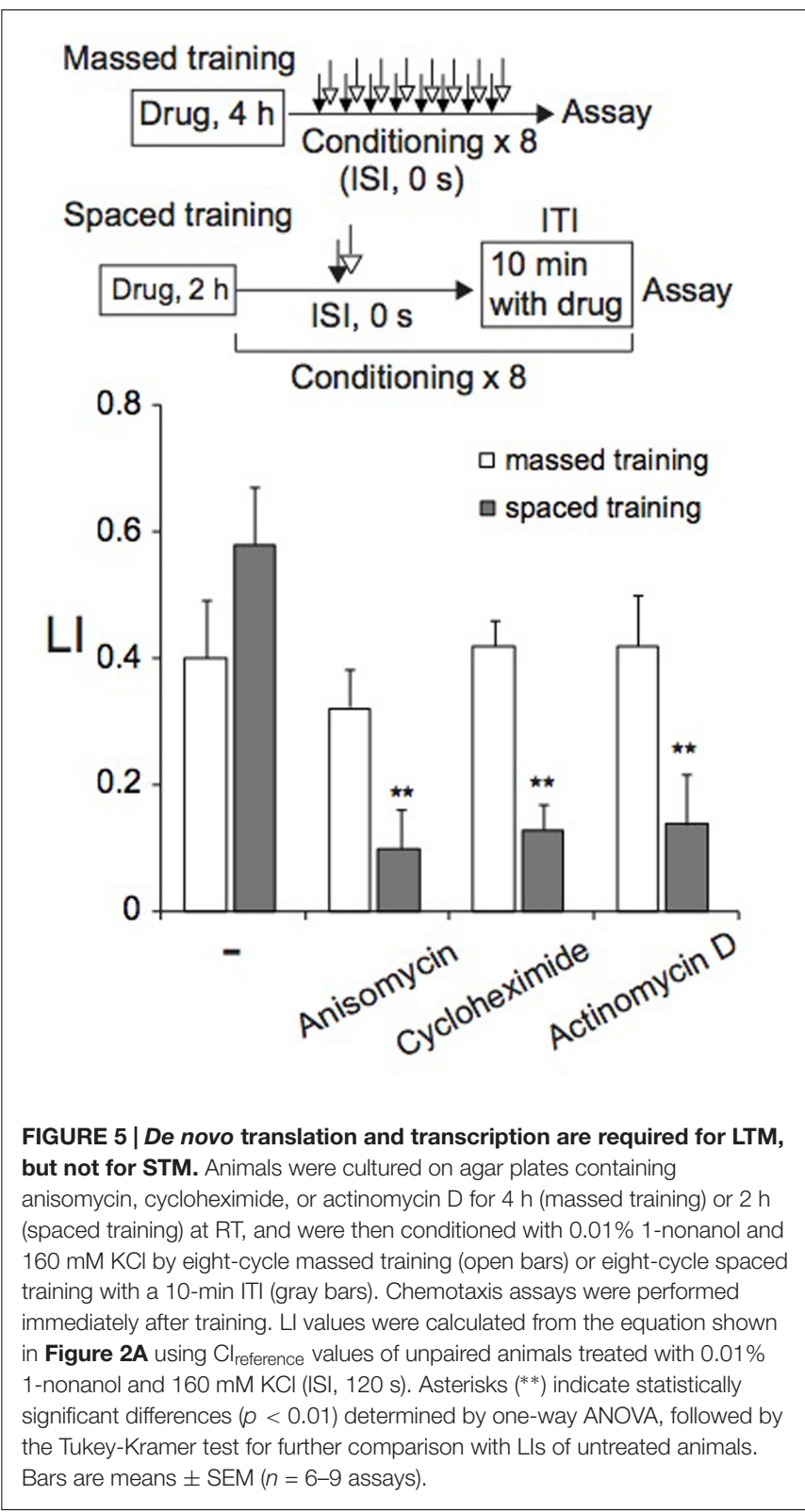

unpaired (ISI, $120 \mathrm{~s}$ ) animals stimulated with 1-nonanol and $\mathrm{KCl}$ from that of paired (ISI, $0 \mathrm{~s}$ ) animals. Together with the results of cold-shock sensitivity described above, these results indicate that memories induced by massed and spaced training are STM and LTM, respectively.

\section{C. elegans Mutants Defective in STM and/or LTM}

The C. elegans genome encodes "learning and memory genes," including $c r h-1$ for the ubiquitous transcription factor CREB (cAMP-responsive element-binding protein), glr-1 for $\alpha$-amino3-hydroxy-5-methyl-4-isoxazolapropionic acid (AMPA)-type, and $n m r-1$ for $N$-methyl-D-aspartate (NMDA)-type glutamate receptor subunits. Previous studies in Aplysia, C. elegans, Drosophila, and mice (e.g., Dash et al., 1990; Dubnau et al., 2003; 


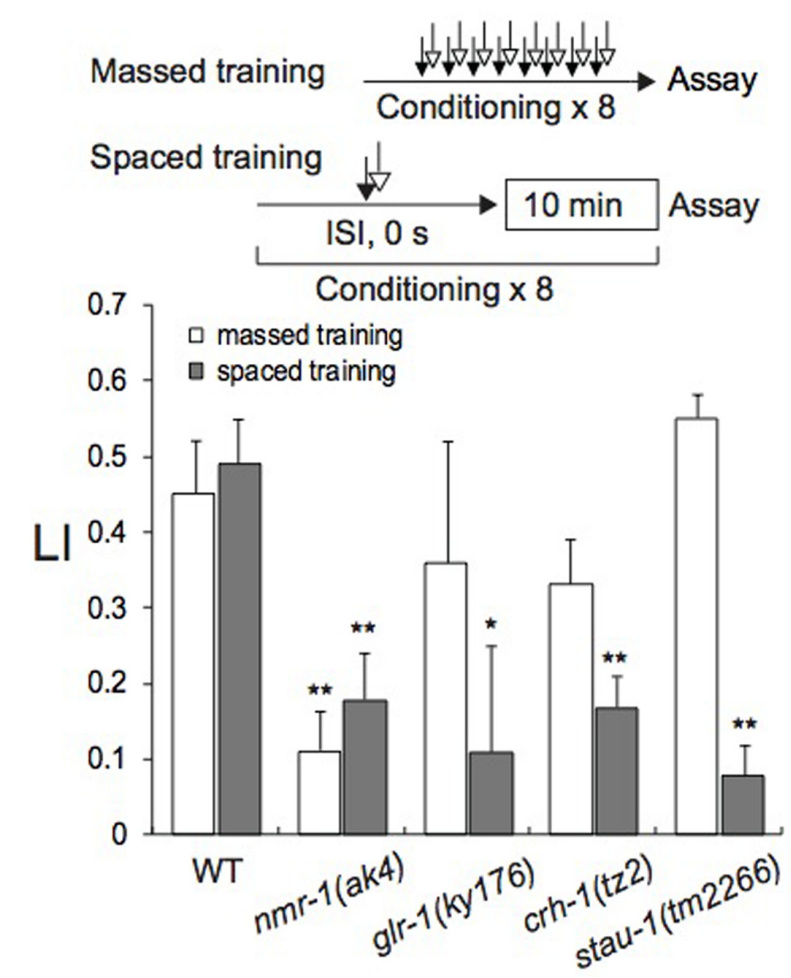

FIGURE 6 | Caenorhabditis elegans mutants defective in learning and memory. Wild-type N2 and mutants were conditioned with $0.1 \%$ 1-nonanol and $160 \mathrm{mM} \mathrm{KCl}$ using eight-cycle massed training (open bars) or eight-cycle spaced training with a 10-min ITI (gray bars). Chemotaxis assays were performed immediately after conditioning. LI values were calculated from the equation shown in Figure 2A using $\mathrm{Cl}_{\text {reference }}$ values of unpaired animals treated with $0.1 \% 1$-nonanol and $160 \mathrm{mM} \mathrm{KCl}$ (ISI, $120 \mathrm{~s})$. Asterisks indicate statistically significant differences $\left({ }^{*} p<0.05,{ }^{* *} p<0.01\right)$ of mutant LIs in comparison with those of the wild-type, using two-sided Student's $t$-test. Data are displayed as means \pm SEM ( $n=6-9$ assays).

Hobert, 2003; Xia et al., 2005; Kano et al., 2008; Kauffman et al., 2010; Amano and Maruyama, 2011; Miyashita et al., 2012; Sasakura and Mori, 2013; Shipton and Paulsen, 2014) have shown that these genes play vital roles in classical conditioning. stau-1, which encodes the double-stranded RNA-binding protein Staufen isoform (LeGendre et al., 2013), has been shown to play crucial roles in classical conditioning in C. elegans and Drosophila (Dubnau et al., 2003; Amano and Maruyama, 2011). Therefore, we also examined whether the gene is involved in memory formation after massed or spaced training. In chemotaxis assays, all mutants as well as wild-type N2 avoided 1-nonanol, but sensitivities of $n m r-1$ (ak4) and $c r h-1(t z 2)$ to $0.01 \%$ 1-nonanol were significantly lower than that of the wild-type (Supplementary Figure S3A). Therefore, 0.1\% 1-nonanol, which produced similar CI values for all strains analyzed, was used for classical conditioning and the chemotaxis assay. All the mutants were attracted to $160 \mathrm{mM} \mathrm{KCl}$ at statistically indistinguishable efficiencies from that of wild-type (Supplementary Figure S3B). Motility of mutant strains before and after training was statistically indistinguishable from that of wild-type (Supplementary Table S2). In the experiments of Figure 6, LI values were calculated by subtracting of CI of unpaired (ISI, $120 \mathrm{~s}$ ) animals stimulated with 1-nonanol and $\mathrm{KCl}$ from that of paired (ISI, $0 \mathrm{~s}$ ) animals.

In comparison to wild-type, $n m r-1(a k 4)$ formed both STM and LTM less effectively after massed and spaced training with $0.1 \%$ 1-nonanol and $160 \mathrm{mM} \mathrm{KCl} \mathrm{(Figure} \mathrm{6).} \mathrm{By} \mathrm{contrast,} \mathrm{crh-1(tz2),}$ glr-1(ky176), and stau-1(tm2266) were successfully conditioned by massed training, but less effectively formed LTM than the wildtype after eight-cycle spaced training. These results demonstrate that only $n m r-1$ among the investigated genes is required for STM, and all genes examined are essential for LTM. No effect of $g l r-1(k y 176)$ and stau-1(tm2266) in the formation of STM is discussed below.

\section{DISCUSSION}

In the present study we developed a classical conditioning paradigm to study associative learning and memory in C. elegans. This appetitive olfactory conditioning with 1 -nonanol and $\mathrm{KCl}$, used as a CS and a US, respectively, shares many of the defining features of associative learning in vertebrate and invertebrate species, as exemplified by classical conditioning. These include contiguity learning, and both short-term and long-term retention of memories. Furthermore, it is also possible to extinguish learned behavior to some extent by extinction learning, in which presentation of a reinforcing stimulus is withheld.

Short-term memory and LTM have successfully been induced with massed training and spaced training, respectively. The only difference between the two training protocols is an ITI, which is also called "a resting interval," between trials in spaced training. LTM formation is dependent on mRNA and protein synthesis, while STM is not. These are the major features of LTM and STM (e.g., Flexner et al., 1962; Agranoff and Klinger, 1964; Barondes and Jarvik, 1964; Stanton and Sarvey, 1984; Bourtchuladze et al., 1994; Nguyen et al., 1994; Tully et al., 1994; Crow et al., 1997; Epstein et al., 2003; Fulton et al., 2005; Kauffman et al., 2010; Amano and Maruyama, 2011). When C. elegans was conditioned with butanone as a CS and bacterial food as a US, STM and LTM were formed (Kauffman et al., 2010). A single treatment of the animal, which was starved for an hour, with $10 \%$ butanone and food for 30 min successfully induced STM, which was no longer observable after $2 \mathrm{~h}$. The single trial also induced LI values similar to those measured immediately after seven-cycle spaced training, although six or seven training sessions were required to retain the memory for 16 or $24 \mathrm{~h}$, respectively. In contrast, in the present study using 1-nonanol and $\mathrm{KCl}$, memory induced by eight-cycle spaced training was retained less than $12 \mathrm{~h}$, and a single trial induced only $\sim 30 \%$ of maximum memory induced after eight-cycle massed training (Figure 3A). These differences may be derived from either a distinct US (food or $\mathrm{KCl}$ ) or the duration of training per cycle $(30 \mathrm{~min}$ vs. $10 \mathrm{~s})$.

In general, when presentation of a CS precedes that of a US by a brief interval, optimal conditioning is observed ("forward conditioning") (Jones, 1962; Schneiderman and Gormezano, 
1964; Hawkins et al., 1986). There are also examples of classical conditioning that simultaneous pairing is as effective, or more effective than forward pairing (e.g., Mahoney and Ayres, 1976; Rescorla, 1980; Tully and Quinn, 1985; Barnet et al., 1991, 1993; Lin and Glanzman, 1997; Lent and Kwon, 2004; Amano and Maruyama, 2011). Consistent with these cases, the present results demonstrate that the most efficacious procedure for appetitive olfactory conditioning is to have consecutive presentation of CS and US without an intervening delay (Figure 2A).

The memory augmentation induced by spaced training is called the spacing effect, which is a common phenomenon in animals, including humans (Carew et al., 1972; Gerber et al., 1998; Rose et al., 2002; Cepeda et al., 2006). The optimal ITI was determined to be $\sim 10 \mathrm{~min}$ for 6 -h retention of LTM (Figure 2B). This is similar to optimal ITIs of other organisms, including Drosophila, honeybees and crickets (Beck et al., 2000; Menzel et al., 2001; Matsumoto and Mizunami, 2002; Giurfa et al., 2009; Rohwedder et al., 2015). The spacing effect has long been known at the behavioral level, but the underlying cellular and molecular mechanisms are not well-understood. Mitogen-activated protein kinase (MAPK) activity has been implicated in memory formation in vertebrates and invertebrates (Kandel, 2001; Kelleher et al., 2004; Mayford, 2007; Cammarota et al., 2008), and recent studies suggest that activation of MAPK during ITIs is necessary for LTM (Ye et al., 2008; Pagani et al., 2009; Li et al., 2016).

We have also analyzed effects of mutations on formation of STM and LTM (Figure 6). $n m r-1(a k 4)$ was defective in formation of both STM and LTM. Mutations in crh-1(tz2), glr-1(ky176), and stau-1(tm2266) affected only LTM. In C. elegans, $n m r-1$ is expressed only in six pairs of neurons (AVA, AVD, ADE, RIM, AVG, and PVC) (Brockie et al., 2001a,b). In these neurons, the NMDA receptor may act as a molecular coincidence detector for 1-nonanol and $\mathrm{KCl}$ signals for synaptic plasticity, where synaptic strengthening required for both STM and LTM can result from coincidental firing of pre- and postsynaptic neurons (Gustafsson and Wingstrom, 1988; Kauer et al., 1988; Bliss and Collingridge, 1993; Bailey et al., 2000; Miyashita et al., 2012). Influx of $\mathrm{Ca}^{2+}$ through glutamate receptors into post-synaptic cells can induce activation of protein kinases such as MAPK and CaMKII (Chen et al., 1998; Bailey et al., 2000; Wang et al., 2007), which phosphorylate the transcription-factor CREB. CREB, encoded by crh-1 (Kimura et al., 2002; Suo et al., 2009; Nishida et al., 2011; Timbers and Rankin, 2011), is a member of the basic region/leucine zipper (bZip) family of transcription factors. It is regulated by increases in intracellular levels of cAMP and $\mathrm{Ca}^{2+}$ (Carlezon et al., 2005), and activates a cascade of genes that leads to LTM (Dash et al., 1990; Yin et al., 1994; Barco and Marie, 2011; Kida and Serita, 2014; Lakhina et al., 2015). The glr-1 gene encodes one subtype of ionotropic glutamate receptor channels, and is critical for LTM formation. Its expression and localization altered by conditioning are necessary for formation of long-term habituation in C. elegans (Rose et al., 2005).
The phenotypic difference between $n m r-1$ and $g l r-1$ may be due to the number of homologs encoded by the genome. Six of the subunits, including four non-NMDA ( $g l r-1, g l r-2, g l r-4$, and $g l r-5)$ and two NMDA ( $n m r-1$ and $n m r-2)$, are expressed in many of the command interneurons, which control forward and backward locomotion (Brockie and Maricq, 2006). During massed training, redundant GLR activities might compensate the missing or reduced activity of GLR-1, while full activity of all the GLR subunits may be required for LTM. During spaced training, activity of redundant homologs may not be strong enough to compensate for the missing or reduced activity of one of the homologs for learning and memory. Similarly, stau-1(tm2266) is a partial loss-of-function mutant (LeGendre et al., 2013), and the reduced activity may be sufficient for STM but not for LTM.

\section{CONCLUSION}

The appetitive olfactory conditioning with 1-nonanol and $\mathrm{KCl}$ shares many features of associative learning observed in other invertebrate and vertebrate. These include contiguity learning, and both short-term and long-term retention of memories. Furthermore, the learned behavior can be extinguished to some extent by extinction learning, in which presentation of reinforcing stimuli is withheld. The formation of LTM, but not STM, was dependent on mRNA and protein synthesis, and required activity of genes shared by other model organisms, including Aplysia, Drosophila, and mice.

Our previous (Amano and Maruyama, 2011) and present studies have now established aversive and appetitive conditioning paradigms with combinations of two defined chemical cues, which may allow us to elucidate neuronal circuit plasticity for learning and memory in C. elegans. Analysis of the two paradigms may give insights into their similarities and differences at neuronal circuit and molecular levels.

\section{AUTHOR CONTRIBUTIONS}

SN and IM conceived and designed the experiments. SN performed the experiments. SN and IM analyzed the data, and wrote and edited the manuscript.

\section{FUNDING}

This work was supported by funding from Okinawa Institute of Science and Technology Graduate University, Okinawa, Japan.

\section{ACKNOWLEDGMENTS}

We thank A. Maricq for $g l r-1(k y 176)$ strain. Other strains were provided by the Caenorhabditis Genetics Center, which is funded 
by the NIH National Center for Research Resources (NCRR), and the National Bioresource Project for the Nematode. We are also grateful to E. Saita for his technical assistance, and members of the Information Processing Biology Unit for discussions and comments on the manuscript.

\section{REFERENCES}

Agranoff, B. W., and Klinger, P. D. (1964). Puromycin effect on memory fixation in the goldfish. Science 146, 952-953. doi: 10.1126/science.146.3646.952

Alexander, J. Jr., Audesirk, T. E., and Audesirk, G. J. (1984). One-trial reward learning in the snail Lymnaea stagnalis. J. Neurobiol. 15, 67-72. doi: 10.1002/ neu. 480150107

Amano, H., and Maruyama, I. N. (2011). Aversive olfactory learning and associative long-term memory in Caenorhabditis elegans. Learn. Mem. 18, 654-665. doi: $10.1101 / \mathrm{lm} .2224411$

Andreatta, M., Fendt, M., Muhlberger, A., Wieser, M. J., Imobersteg, S., Yarali, A., et al. (2012). Onset and offset of aversive events establish distinct memories requiring fear and reward networks. Learn. Mem. 19, 518-526. doi: 10.1101/ $\operatorname{lm} .026864 .112$

Andreatta, M., and Pauli, P. (2015). Appetitive vs. aversive conditioning in humans. Front. Behav. Neurosci. 9:128. doi: 10.3389/fnbeh.2015.00128

Austin, A. J., and Duka, T. (2010). Mechanisms of attention for appetitive and aversive outcomes in Pavlovian conditioning. Behav. Brain Res. 213, 19-26. doi: 10.1016/j.bbr.2010.04.019

Bailey, C. H., Giustetto, M., Huang, Y. Y., Hawkins, R. D., and Kandel, E. R. (2000). Is heterosynaptic modulation essential for stabilizing Hebbian plasticity and memory? Nat. Rev. Neurosci. 1, 11-20. doi: 10.1038/35036191

Barco, A., and Marie, H. (2011). Genetic approaches to investigate the role of CREB in neuronal plasticity and memory. Mol. Neurobiol. 44, 330-349. doi: 10.1007/s12035-011-8209-x

Bargmann, C. I. (2006). Chemosensation in C. elegans. WormBook 25, 1-29. doi: 10.1895/wormbook.1.123.1

Bargmann, C. I., Hartwieg, E., and Horvitz, H. R. (1993). Odorant-selective genes and neurons mediate olfaction in C. elegans. Cell 74, 515-527. doi: 10.1016/ 0092-8674(93)80053-H

Bargmann, C. I., and Horvitz, H. R. (1991). Chemosensory neurons with overlapping functions direct chemotaxis to multiple chemicals in C. elegans. Neuron 7, 729-742. doi: 10.1016/0896-6273(91)90276-6

Bargmann, C. I., and Mori, I. (1997). "Chemotaxis and thermotaxis," in C. elegans II, eds D. L. Riddle, T. Blumenthal, B. J. Meyer, and J. R. Priess (Cold Spring Harbor, NY: Cold Spring Harbor Laboratory Press), 717-737.

Barnet, R. C., Arnold, H. M., and Miller, R. R. (1991). Simultaneous conditioning demonstrated in second-order conditioning: evidence for similar associative structure in forward and simultaneous conditioning. Learn. Motiv. 22, 253-268. doi: 10.1016/0023-9690(91)90008-V

Barnet, R. C., Grahame, N. J., and Miller, R. R. (1993). Temporal encoding as a determinant of blocking. J. Exp. Psychol. Anim. Behav. Process 19, 327-341. doi: 10.1037/0097-7403.19.4.327

Barondes, S. H., and Jarvik, M. E. (1964). The influence of actinomycin-D on brain Rna synthesis and on memory. J. Neurochem. 11, 187-195. doi: 10.1111/j.14714159.1964.tb06128.x

Beck, C. D., Schroeder, B., and Davis, R. L. (2000). Learning performance of normal and mutant Drosophila after repeated conditioning trials with discrete stimuli. J. Neurosci. 20, 2944-2953.

Bliss, T. V., and Collingridge, G. L. (1993). A synaptic model of memory: long-term potentiation in the hippocampus. Nature 361, 31-39. doi: 10.1038/361031a0

Bourtchuladze, R., Frenguelli, B., Blendy, J., Cioffi, D., Schutz, G., and Silva, A. J. (1994). Deficient long-term memory in mice with a targeted mutation of the cAMP-responsive element-binding protein. Cell 79, 59-68. doi: 10.1016/00928674(94)90400-6

Bouton, M. E., and Peck, C. A. (1989). Context effects on conditioning, extinction, and reinstatement in an appetitive conditioning preparation. Anim. Learn. Behav. 17, 188-198. doi: 10.3758/Bf03207634

Brenner, S. (1974). The genetics of Caenorhabditis elegans. Genetics 77, 71-94.

\section{SUPPLEMENTARY MATERIAL}

The Supplementary Material for this article can be found online at: http://journal.frontiersin.org/article/10.3389/fnbeh. 2017.00080/full\#supplementary-material

Brockie, P. J., Madsen, D. M., Zheng, Y., Mellem, J., and Maricq, A. V. (2001a). Differential expression of glutamate receptor subunits in the nervous system of Caenorhabditis elegans and their regulation by the homeodomain protein UNC-42. J. Neurosci. 21, 1510-1522.

Brockie, P. J., and Maricq, A. V. (2006). Ionotropic glutamate receptors: genetics, behavior and electrophysiology. WormBook 19, 1-16. doi: 10.1895/wormbook. 1.61 .1

Brockie, P. J., Mellem, J. E., Hills, T., Madsen, D. M., and Maricq, A. V. (2001b). The C. elegans glutamate receptor subunit NMR-1 is required for slow NMDAactivated currents that regulate reversal frequency during locomotion. Neuron 31, 617-630. doi: 10.1016/S0896-6273(01)00394-4

Burke, C. J., Huetteroth, W., Owald, D., Perisse, E., Krashes, M. J., Das, G., et al. (2012). Layered reward signalling through octopamine and dopamine in Drosophila. Nature 492, 433-437. doi: 10.1038/nature11614

Cammarota, M., Bevilaqua, L. R., Medina, J. H., and Izquierdoi, I. (2008). ERK1/2 and CaMKII-mediated events in memory formation: is $5 \mathrm{HT}$ regulation involved? Behav. Brain Res. 195, 120-128. doi: 10.1016/j.bbr.2007.11.029

Carew, T. J., Pinsker, H. M., and Kandel, E. R. (1972). Long-term habituation of a defensive withdrawal reflex in Aplysia. Science 175, 451-454. doi: 10.1126/ science.175.4020.451

Carlezon, W. A. Jr., Duman, R. S., and Nestler, E. J. (2005). The many faces of CREB. Trends Neurosci. 28, 436-445. doi: 10.1016/j.tins.2005.06.005

Cepeda, N. J., Pashler, H., Vul, E., Wixted, J. T., and Rohrer, D. (2006). Distributed practice in verbal recall tasks: a review and quantitative synthesis. Psychol. Bull. 132, 354-380. doi: 10.1037/0033-2909.132.3.354

Chen, H. J., Rojas-Soto, M., Oguni, A., and Kennedy, M. B. (1998). A synaptic RasGTPase activating protein (p135 SynGAP) inhibited by CaM kinase II. Neuron 20, 895-904. doi: 10.1016/S0896-6273(00)80471-7

Chi, C. A., Clark, D. A., Lee, S., Biron, D., Luo, L., Gabel, C. V., et al. (2007). Temperature and food mediate long-term thermotactic behavioral plasticity by association-independent mechanisms in C. elegans. J. Exp. Biol. 210, 4043-4052. doi: 10.1242/jeb.006551

Crow, T., Siddiqi, V., and Dash, P. K. (1997). Long-term enhancement but not short-term in Hermissenda is dependent upon mRNA synthesis. Neurobiol. Learn. Mem. 68, 343-350. doi: 10.1006/nlme.1997.3779

Dash, P. K., Hochner, B., and Kandel, E. R. (1990). Injection of the cAMPresponsive element into the nucleus of Aplysia sensory neurons blocks longterm facilitation. Nature 345, 718-721. doi: 10.1038/345718a0

de Bono, M., and Maricq, A. V. (2005). Neuronal substrates of complex behaviors in C. elegans. Annu. Rev. Neurosci. 28, 451-501. doi: 10.1146/annurev.neuro.27. 070203.144259

Dostalek, C. (1976). Backward conditioning in man and the criteria of conditioning. Act. Nerv. Super. 18, 26-30.

Driscoll, M., and Kaplan, J. (1997). "Mechanotransduction," in C. elegans II, eds D. L. Riddle, T. Blumenthal, B. J. Meyer, and J. R. Priess (Cold Spring Harbor, NY: Cold Spring Harbor Laboratory Press), 645-677.

Dubnau, J., Chiang, A. S., Grady, L., Barditch, J., Gossweiler, S., McNeil, J., et al. (2003). The staufen/pumilio pathway is involved in Drosophila long-term memory. Curr. Biol. 13, 286-296. doi: 10.1016/S0960-9822(03)00064-2

Durkovic, R. G., and Damianopoulos, E. N. (1986). Forward and backward classical conditioning of the flexion reflex in the spinal cat. J. Neurosci. 6, 2921-2925.

Dusenbery, D. B. (1974). Analysis of chemotaxis in the nematode Caenorhabditis elegans by countercurrent separation. J. Exp. Zool. 188, 41-47. doi: 10.1002/jez. 1401880105

Eisenhardt, D. (2014). Molecular mechanisms underlying formation of long-term reward memories and extinction memories in the honeybee (Apis mellifera). Learn. Mem. 21, 534-542. doi: 10.1101/lm.033118.113

Epstein, H. T., Child, F. M., Kuzirian, A. M., and Alkon, D. L. (2003). Time windows for effects of protein synthesis inhibitors on Pavlovian conditioning 
in Hermissenda: behavioral aspects. Neurobiol. Learn. Mem. 79, 127-131. doi: 10.1016/S1074-7427(02)00020-5

Fanselow, M. S., and Wassum, K. M. (2016). The origins and organization of vertebrate pavlovian conditioning. Cold Spring Harb. Perspect. Biol. 8:a021717. doi: 10.1101/cshperspect.a021717

Flexner, J. B., Flexner, L. B., Stellar, E., De La Haba, G., and Roberts, R. B. (1962). Inhibition of protein synthesis in brain and learning and memory following puromycin. J. Neurochem. 9, 595-605. doi: 10.1111/j.1471-4159.1962.tb04216.x

Flood, J. F., Rosenzweig, M. R., Bennett, E. L., and Orme, A. E. (1973). The influence of duration of protein synthesis inhibition on memory. Physiol. Behav. 10, 555-562. doi: 10.1016/0031-9384(73)90221-7

Fulton, D., Kemenes, I., Andrew, R. J., and Benjamin, P. R. (2005). A single timewindow for protein synthesis-dependent long-term memory formation after one-trial appetitive conditioning. Eur. J. Neurosci. 21, 1347-1358. doi: 10.1111/ j.1460-9568.2005.03970.x

Gerber, B., Wustenberg, D., Schutz, A., and Menzel, R. (1998). Temporal determinants of olfactory long-term retention in honeybee classical conditioning: nonmonotonous effects of the training trial interval. Neurobiol. Learn. Mem. 69, 71-78. doi: 10.1006/nlme.1997.3801

Gerber, B., Yarali, A., Diegelmann, S., Wotjak, C. T., Pauli, P., and Fendt, M. (2014). Pain-relief learning in flies, rats, and man: basic research and applied perspectives. Learn. Mem. 21, 232-252. doi: 10.1101/lm.032995.113

Giurfa, M., Fabre, E., Flaven-Pouchon, J., Groll, H., Oberwallner, B., Vergoz, V., et al. (2009). Olfactory conditioning of the sting extension reflex in honeybees: memory dependence on trial number, interstimulus interval, intertrial interval, and protein synthesis. Learn. Mem. 16, 761-765. doi: 10.1101/lm.1603009

Gray, J. M., Hill, J. J., and Bargmann, C. I. (2005). A circuit for navigation in Caenorhabditis elegans. Proc. Natl. Acad. Sci. U.S.A. 102, 3184-3191. doi: 10.1073/pnas.0409009101

Gustafsson, B., and Wingstrom, H. (1988). Physiological mechanisms underlying long-term potentiation. Trends Neurosci. 11, 156-162. doi: 10.1016/01662236(88)90142-7

Hawkins, R. D., Carew, T. J., and Kandel, E. R. (1986). Effects of interstimulus interval and contingency on classical conditioning of the Aplysia siphon withdrawal reflex. J. Neurosci. 6, 1695-1701.

Hedgecock, E. M., and Russell, R. L. (1975). Normal and mutant thermotaxis in the nematode Caenorhabditis elegans. Proc. Natl. Acad. Sci. U.S.A. 72, 4061-4065. doi: $10.1073 /$ pnas.72.10.4061

Hobert, O. (2003). Behavioral plasticity in C. elegans: paradigms, circuits, genes. J. Neurobiol. 54, 203-223. doi: 10.1002/neu.10168

Jarome, T. J., and Helmstetter, F. J. (2014). Protein degradation and protein synthesis in long-term memory formation. Front. Mol. Neurosci. 7:61. doi: $10.3389 /$ fnmol.2014.00061

Jones, J. E. (1962). Contiguity and reinforcement in relation to CS-UCS intervals in classical aversive conditioning. Psychol. Rev. 69, 176-185. doi: 10.1037/ h0049387

Kandel, E. R. (2001). The molecular biology of memory storage: a dialogue between genes and synapses. Science 294, 1030-1038. doi: 10.1126/science. 1067020

Kano, T., Brockie, P. J., Sassa, T., Fujimoto, H., Kawahara, Y., Iino, Y., et al. (2008). Memory in Caenorhabditis elegans is mediated by NMDA-type ionotropic glutamate receptors. Curr. Biol. 18, 1010-1015. doi: 10.1016/j.cub.2008.05.051

Kauer, J. A., Malenka, R. C., and Nicoll, R. A. (1988). A persistent postsynaptic modification mediates long-term potentiation in the hippocampus. Neuron 1 , 911-917. doi: 10.1016/0896-6273(88)90148-1

Kauffman, A. L., Ashraf, J. M., Corces-Zimmerman, M. R., Landis, J. N., and Murphy, C. T. (2010). Insulin signaling and dietary restriction differentially influence the decline of learning and memory with age. PLoS Biol. 8:e1000372. doi: 10.1371/journal.pbio.1000372

Kelleher, R. J. III, Govindarajan, A., Jung, H. Y., Kang, H., and Tonegawa, S. (2004). Translational control by MAPK signaling in long-term synaptic plasticity and memory. Cell 116, 467-479. doi: 10.1016/S0092-8674(04)00115-1

Kida, S., and Serita, T. (2014). Functional roles of CREB as a positive regulator in the formation and enhancement of memory. Brain Res. Bull. 105, 17-24. doi: 10.1016/j.brainresbull.2014.04.011

Kimura, Y., Corcoran, E. E., Eto, K., Gengyo-Ando, K., Muramatsu, M. A., Kobayashi, R., et al. (2002). A CaMK cascade activates CRE-mediated transcription in neurons of Caenorhabditis elegans. EMBO Rep. 3, 962-966. doi: 10.1093/embo-reports/kvf191
Kobayashi, K., Nakano, S., Amano, M., Tsuboi, D., Nishioka, T., Ikeda, S., et al. (2016). Single-cell memory regulates a neural circuit for sensory behavior. Cell Rep. 14, 11-21. doi: 10.1016/j.celrep.2015.11.064

Lakhina, V., Arey, R. N., Kaletsky, R., Kauffman, A., Stein, G., Keyes, W., et al. (2015). Genome-wide functional analysis of CREB/long-term memory-dependent transcription reveals distinct basal and memory gene expression programs. Neuron 85, 330-345. doi: 10.1016/j.neuron.2014. 12.029

LeGendre, J. B., Campbell, Z. T., Kroll-Conner, P., Anderson, P., Kimble, J., and Wickens, M. (2013). RNA targets and specificity of Staufen, a double-stranded RNA-binding protein in Caenorhabditis elegans. J. Biol. Chem. 288, 2532-2545. doi: 10.1074/jbc.M112.397349

Lent, D. D., and Kwon, H. W. (2004). Antennal movements reveal associative learning in the American cockroach Periplaneta americana. J. Exp. Biol. 207, 369-375. doi: 10.1242/jeb.00736

Li, Q., Zhang, X., Hu, W., Liang, X., Zhang, F., Wang, L., et al. (2016). Importin7 mediates memory consolidation through regulation of nuclear translocation of training-activated MAPK in Drosophila. Proc. Natl. Acad. Sci. U.S.A. 113, 3072-3077. doi: 10.1073/pnas.1520401113

Lin, X. Y., and Glanzman, D. L. (1997). Effect of interstimulus interval on pairinginduced LTP of Aplysia sensorimotor synapses in cell culture. J. Neurophysiol. 77, 667-674.

Mahoney, W. J., and Ayres, J. J. (1976). One-trial simultaneous and backward fear conditioning as reflected in conditioned suppression of licking in rats. Anim. Learn. Behav. 4, 357-362. doi: 10.3758/BF03214421

Martin-Soelch, C., Linthicum, J., and Ernst, M. (2007). Appetitive conditioning: neural bases and implications for psychopathology. Neurosci. Biobehav. Rev. 31, 426-440. doi: 10.1016/j.neubiorev.2006.11.002

Matsumoto, Y., and Mizunami, M. (2002). Temporal determinants of long-term retention of olfactory memory in the cricket Gryllus bimaculatus. J. Exp. Biol. 205, 1429-1437.

Mayford, M. (2007). Protein kinase signaling in synaptic plasticity and memory. Curr. Opin. Neurobiol. 17, 313-317. doi: 10.1016/j.conb.2007.05.001

McDannald, M. A., Lucantonio, F., Burke, K. A., Niv, Y., and Schoenbaum, G. (2011). Ventral striatum and orbitofrontal cortex are both required for modelbased, but not model-free, reinforcement learning. J. Neurosci. 31, 2700-2705. doi: 10.1523/Jneurosci.5499-10.2011

Menzel, R., Manz, G., Menzel, R., and Greggers, U. (2001). Massed and spaced learning in honeybees: the role of CS, US, the intertrial interval, and the test interval. Learn. Mem. 8, 198-208. doi: 10.1101/lm.40001

Michel, M., Green, C. L., and Lyons, L. C. (2011). PKA and PKC are required for long-term but not short-term in vivo operant memory in Aplysia. Learn. Mem. 18, 19-23. doi: 10.1101/lm.2026311

Miyashita, T., Oda, Y., Horiuchi, J., Yin, J. C., Morimoto, T., and Saitoe, M. (2012). $\mathrm{Mg}(2+)$ block of Drosophila NMDA receptors is required for long-term memory formation and CREB-dependent gene expression. Neuron 74, 887-898. doi: 10.1016/j.neuron.2012.03.039

Mizumori, S. J., Channon, V., Rosenzweig, M. R., and Bennett, E. L. (1987). Anisomycin impairs long-term working memory in a delayed alternation task. Behav. Neural. Biol. 47, 1-6. doi: 10.1016/S0163-1047(87)90101-4

Mohri, A., Kodama, E., Kimura, K. D., Koike, M., Mizuno, T., and Mori, I. (2005). Genetic control of temperature preference in the nematode Caenorhabditis elegans. Genetics 169, 1437-1450. doi: 10.1534/genetics.104.036111

Myers, K. M., and Davis, M. (2002). Behavioral and neural analysis of extinction. Neuron 36, 567-584. doi: 10.1016/S0896-6273(02)01064-4

Nargeot, R., and Simmers, J. (2011). Neural mechanisms of operant conditioning and learning-induced behavioral plasticity in Aplysia. Cell Mol. Life Sci. 68, 803-816. doi: 10.1007/s00018-010-0570-9

Nguyen, P. V., Abel, T., and Kandel, E. R. (1994). Requirement of a critical period of transcription for induction of a late phase of LTP. Science 265, 1104-1107. doi: 10.1126/science. 8066450

Nishida, Y., Sugi, T., Nonomura, M., and Mori, I. (2011). Identification of the AFD neuron as the site of action of the CREB protein in Caenorhabditis elegans thermotaxis. EMBO Rep. 12, 855-862. doi: 10.1038/embor.2011.120

Nuttley, W. M., Atkinson-Leadbeater, K. P., and Van Der Kooy, D. (2002). Serotonin mediates food-odor associative learning in the nematode Caenorhabditis elegans. Proc. Natl. Acad. Sci. U.S.A. 99, 12449-12454. doi: 10.1073/pnas.192101699 
Ortiz, C. O., Faumont, S., Takayama, J., Ahmed, H. K., Goldsmith, A. D., Pocock, R., et al. (2009). Lateralized gustatory behavior of C. elegans is controlled by specific receptor-type guanylyl cyclases. Curr. Biol. 19, 996-1004. doi: $10.1016 /$ j.cub.2009.05.043

Pagani, M. R., Oishi, K., Gelb, B. D., and Zhong, Y. (2009). The phosphatase SHP2 regulates the spacing effect for long-term memory induction. Cell 139, 186-198. doi: 10.1016/j.cell.2009.08.033

Pavlov, I. P. (1927). Conditioned Reflexes: An Investigation of the Physiological Activity of the Cerebral Cortex. London: Oxford University Press.

Rescorla, R. A. (1980). Simultaneous and successive associations in sensory preconditioning. J. Exp. Psychol. Anim. Behav. Process. 6, 207-216. doi: 10.1037/ 0097-7403.6.3.207

Riddle, D. L., and Albert, P. S. (1997). "Genetic and environmental regulation of dauer larva development," in C. elegans II, eds D. L. Riddle, T. Blumenthal, B. J. Meyer, and J. R. Priess (Cold Spring Harbor, NY: Cold Spring Harbor Laboratory Press), 739-768.

Rohwedder, A., Selcho, M., Chassot, B., and Thum, A. S. (2015). Neuropeptide F neurons modulate sugar reward during associative olfactory learning of Drosophila larvae. J. Comp. Neurol. 523, 2637-2664. doi: 10.1002/cne.23873

Rose, J. K., Kaun, K. R., and Rankin, C. H. (2002). A new group-training procedure for habituation demonstrates that presynaptic glutamate release contributes to long-term memory in Caenorhabditis elegans. Learn. Mem. 9, 130-137. doi: $10.1101 / \mathrm{lm} .46802$

Rose, J. K., Sangha, S., Rai, S., Norman, K. R., and Rankin, C. H. (2005). Decreased sensory stimulation reduces behavioral responding, retards development, and alters neuronal connectivity in Caenorhabditis elegans. J. Neurosci. 25, 7159-7168. doi: 10.1523/JNEUROSCI.1833-05.2005

Sasakura, H., and Mori, I. (2013). Behavioral plasticity, learning, and memory in C. elegans. Curr. Opin. Neurobiol. 23, 92-99. doi: 10.1016/j.conb.2012.09.005

Schneiderman, N., and Gormezano, I. (1964). Conditioning of the nictitating membrane of the rabbit as a function of CS-US interval. J. Comp. Physiol. Psychol. 57, 188-195. doi: 10.1037/h0043419

Schwaerzel, M., Monastirioti, M., Scholz, H., Friggi-Grelin, F., Birman, S., and Heisenberg, M. (2003). Dopamine and octopamine differentiate between aversive and appetitive olfactory memories in Drosophila. J. Neurosci. 23, 10495-10502.

Shipton, O. A., and Paulsen, O. (2014). GluN2A and GluN2B subunit-containing NMDA receptors in hippocampal plasticity. Philos. Trans. R. Soc. Lond. B Biol. Sci. 369:20130163. doi: 10.1098/rstb.2013.0163

Spetch, M. L., Wilkie, D. M., and Pinel, J. P. L. (1981). Backward conditioning: a reevaluation of the empirical evidence. Psychol. Bull. 89, 163-175. doi: 10.1037/ 0033-2909.89.1.163

Stanton, P. K., and Sarvey, J. M. (1984). Blockade of long-term potentiation in rat hippocampal CA1 region by inhibitors of protein synthesis. J. Neurosci. 4, 3080-3088.

Stein, G. M., and Murphy, C. T. (2014). C. elegans positive olfactory associative memory is a molecularly conserved behavioral paradigm. Neurobiol. Learn. Mem. 115, 86-94. doi: 10.1016/j.nlm.2014.07.011

Suo, S., Culotti, J. G., and Van Tol, H. H. (2009). Dopamine counteracts octopamine signalling in a neural circuit mediating food response in C. elegans. EMBO J. 28, 2437-2448. doi: 10.1038/emboj.2009.194

Suzuki, A., Josselyn, S. A., Frankland, P. W., Masushige, S., Silva, A. J., and Kida, S. (2004). Memory reconsolidation and extinction have distinct temporal and biochemical signatures. J. Neurosci. 24, 4787-4795. doi: 10.1523/JNEUROSCI. 5491-03.2004
Tanimoto, H., Heisenberg, M., and Gerber, B. (2004). Experimental psychology: event timing turns punishment to reward. Nature 430:983. doi: 10.1038/ 430983a

Timbers, T. A., and Rankin, C. H. (2011). Tap withdrawal circuit interneurons require CREB for long-term habituation in Caenorhabditis elegans. Behav. Neurosci. 125, 560-566. doi: 10.1037/a0024370

Torayama, I., Ishihara, T., and Katsura, I. (2007). Caenorhabditis elegans integrates the signals of butanone and food to enhance chemotaxis to butanone. J. Neurosci. 27, 741-750. doi: 10.1523/JNEUROSCI.4312-06.2007

Tully, T., Preat, T., Boynton, S. C., and Del Vecchio, M. (1994). Genetic dissection of consolidated memory in Drosophila. Cell 79, 35-47. doi: 10.1016/00928674(94)90398-0

Tully, T., and Quinn, W. G. (1985). Classical conditioning and retention in normal and mutant Drosophila melanogaster. J. Comp. Physiol. A 157, 263-277. doi: 10.1007/BF01350033

Wang, J. Q., Fibuch, E. E., and Mao, L. (2007). Regulation of mitogen-activated protein kinases by glutamate receptors. J. Neurochem. 100, 1-11. doi: 10.1111/j. 1471-4159.2006.04208.x

Ward, S. (1973). Chemotaxis by the nematode Caenorhabditis elegans: identification of attractants and analysis of the response by use of mutants. Proc. Natl. Acad. Sci. U.S.A. 70, 817-821. doi: 10.1073/pnas.70.3.817

Ward, S., Thomson, N., White, J. G., and Brenner, S. (1975). Electron microscopical reconstruction of the anterior sensory anatomy of the nematode Caenorhabditis elegans. J. Comp. Neurol. 160, 313-337. doi: 10.1002/cne.901600305

Ware, R. W., Clark, D., Crossland, K., and Russell, R. L. (1975). The nerve ring of the nematode Caenorhabditis elegans: sensory input and motor output. J. Compar. Neurol. 162, 71-110. doi: 10.1002/cne.901620106

White, J. G., Southgate, E., Thomson, J. N., and Brenner, S. (1986). The structure of the nervous system of the nematode Caenorhabditis elegans. Philos. Trans. $R$. Soc. Lond. B Biol. Sci. 314, 1-340. doi: 10.1098/rstb.1986.0056

Wicks, S. R., de Vries, C. J., van Luenen, H. G., and Plasterk, R. H. (2000). CHE-3, a cytosolic dynein heavy chain, is required for sensory cilia structure and function in Caenorhabditis elegans. Dev. Biol. 221, 295-307. doi: 10.1006/dbio.2000.9686

Xia, S., Miyashita, T., Fu, T. F., Lin, W. Y., Wu, C. L., Pyzocha, L., et al. (2005). NMDA receptors mediate olfactory learning and memory in Drosophila. Curr. Biol. 15, 603-615. doi: 10.1016/j.cub.2005.02.059

Ye, X., Shobe, J. L., Sharma, S. K., Marina, A., and Carew, T. J. (2008). Small G proteins exhibit pattern sensitivity in MAPK activation during the induction of memory and synaptic facilitation in Aplysia. Proc. Natl. Acad. Sci. U.S.A. 105, 20511-20516. doi: 10.1073/pnas.0808110105

Yin, J. C., Wallach, J. S., Del Vecchio, M., Wilder, E. L., Zhou, H., Quinn, W. G., et al. (1994). Induction of a dominant negative CREB transgene specifically blocks long-term memory in Drosophila. Cell 79, 49-58. doi: 10.1016/00928674(94)90399-9

Conflict of Interest Statement: The authors declare that the research was conducted in the absence of any commercial or financial relationships that could be construed as a potential conflict of interest.

Copyright (c) 2017 Nishijima and Maruyama. This is an open-access article distributed under the terms of the Creative Commons Attribution License (CC BY). The use, distribution or reproduction in other forums is permitted, provided the original author(s) or licensor are credited and that the original publication in this journal is cited, in accordance with accepted academic practice. No use, distribution or reproduction is permitted which does not comply with these terms. 